\title{
Following up on a Margalevian concept: Interactions and exchanges among adjacent parcels of coastal landscapes*
}

\author{
I. VALIELA ${ }^{1}$, J.L. BOWEN ${ }^{1}$, M.L. COLE ${ }^{1}$, K.D. KROEGER ${ }^{1}$, D. LAWRENCE ${ }^{1,2}$, W.J. \\ PABICH $^{3,4}$, G. TOMASKY ${ }^{1}$ and S. MAZZILLI ${ }^{1}$ \\ ${ }^{1}$ Boston University Marine Program, Marine Biological Laboratory, Woods Hole MA 02543, USA. \\ ${ }_{2}^{2}$ Present address: LUMCON, 8124 Hwy 56, Chauvin LA 70344, USA. \\ ${ }^{3}$ Department of Civil and Environmental Engineering, Massachusetts Institute of Technology, Cambridge MA 02138, USA. \\ ${ }^{4}$ Present address: Environmental Defense, 6 North Market Building, Faneuil Hall Marketplace, Boston MA 02109, USA.
}

This essay is dedicated to Maria Mir, colleague, companion, sounding board, and artist, who has provided lifelong inestimable support for Ramón Margalef's contribution to environmental science.

\begin{abstract}
SUMMARY: Some decades ago Margalef speculated that study of the exchanges across boundaries that separate different types of ecological systems would provide significant insights about properties and processes within the units that make up ecological mosaics. Although such boundaries might be difficult to define, it seemed likely that such exchanges among units would influence the function and structure of the adjoined systems. In this paper we explore exchanges across such ecological boundaries in coastal ecosystems in Cape Cod, Massachusetts, and elsewhere. We find that, indeed, definition of such boundaries is ambiguous, but study of the exchanges is more useful. In the Cape Cod system, water transport down-gradient is the dominant mechanism exerting influence on down-gradient systems. The direction of ecological control across such boundaries is largely asymmetrical, and properties of up-gradient units exert significant influence on down-gradient units. General properties of donor and receptor parcels are hard to discern, but clearly, parcels making up an ecological mosaic are not independent units, but are coupled by transfers from upgradient tesserae. Studies of controls of ecological systems need to include inter-unit influences as well as internal mechanisms.
\end{abstract}

Key words: Boundaries, ecological mosaics, coastal ecosystems, coastal watersheds, vadose zone, groundwater, estuaries, salt marsh, seagrass meadows, DIN, DON, DOC.

\section{INTRODUCTION}

Ramón Margalef has been a source of challenging new ideas, grand syntheses, and of new ways to relate ecology, evolution, and other disciplines for our community of researchers and students for more than half a century. Ramón has been -perhaps not a model, for Margalef surely cannot be copied- but

\footnotetext{
*Received August 2, 2001. Accepted August 16, 2001.
}

rather an example of learning and of daring to think in extraordinarily innovative ways. To have a conversation with Ramón is be involved in an exciting exploration, taking headlong leaps across boundaries, to mull relationships unseen by most of us, to get a feeling for the meaning of genius. And, to see all this done effortlessly, with great generosity of spirit, and utter lack of pretension: there is no more unassuming member of our community than Ramón Margalef, in spite of his accomplishments. 
Part of the genius of Ramón Margalef is that his thinking and work move effortlessly through, and profit from, what the rest of us may perceive as limiting boundaries. Ramón crosses disciplines to see new relationships, and has also not been shy about crossing ecological boundaries, working in and comparing terrestrial systems, reservoirs, ponds, lakes, rivers, estuaries, upwellings, the deep sea, or the biosphere and other planets. Non-scientific bounds are crossed as well: Margalef easily crosses linguistic barriers. He writes accessibly in Catalán, Castilian, German, French, English; his latest book (Margalef, 2000) -no doubt not his last-is written in three different languages, to reach wider audiences.

Margalef's oeuvre has enormous breadth, and has in many ways pushed ecology in new directions and across different boundaries. In this paper we take the opportunity to dwell on just one of the many topics in which Margalef has forced new insights: the matter of boundaries among units -which we can call ecological tesserae- within environmental mosaics.

Many authors have examined boundaries between adjoining ecological tesserae. For example, most texts in ecology discuss ecotones (Shelford, 1963), and in general, refer to the transition of species composition across ecotones, and of a presumed increment of species richness at such boundaries. This richness is due, most likely, to a partial overlap in species lists at regions between adjoining parcels containing different taxonomic assemblages. The adjoining units can be successional stages or distinct habitat parcels.

Thus most ecologists have thought of boundaries merely as places where species lists show some change. Early on, Margalef went beyond this notion, suggesting that a more incisive look at these bounds would show much ecological activity. Understanding the dynamics at such boundaries could tell us about the relative organization of the adjoining parcels of environment and could reveal major controls exerted on one parcel by adjoining ones. Similar considerations appear in more recent writings by other researchers (Risser, 1990).

The issue of dynamics of boundaries is briefly mentioned in an early paper by Margalef (1962): “... son frecuentes sistemas en que se hallan en contacto subsistemas con diverso grado de organización...el acoplamiento de elementos de estos sistemas tiene interés, porque...(h)ay un flujo...entre los...sistemas...el sistema con más (organización)...encauza las actividades del otro."

The concept of functionally-important boundaries is developed somewhat more in the brief but magisterial book, "Perspectives in Ecological Theory" (Margalef, 1967). There Margalef points out that we most often define communities or ecosystems based on descriptions of typical locations in the field, but that the boundaries or ecotones that presumedly separate these typical tesserae are frequently hard to define in the field. Rather than focus effort on mere definition of systems and demarcation of boundaries, Margalef suggests that it might be more fruitful to consider the likely exchanges or interplay among the adjoining systems, and points out that Shelford's choice of the term "ecotone" insightfully includes an etymological sense (from the Greek $\tau$ ovo $\sigma$ ) that there is a "tension" among the adjoining ecological parcels. Because of the "tension" between such adjoining parcels, Margalef concludes, the tesserae are best studied in the context of the adjoining systems.

This dynamic sense of boundaries among systems is further developed in Chapter 26, "Fronteras $o$ interfases asimétricas" in Margalef's text "Ecología" (Margalef, 1974). There, ecological boundaries are examined, and an argument is made that there are active processes through these boundaries, that the effects of these processes are of sufficient magnitude to actually control structure of the adjoining systems, and that the direction of the controls is most often asymmetric. In addition, the chapter discusses exchanges of dissolved and particulate matter, and of consumers across boundaries in coastal bentho-pelagic coupling, rivers, and terrestrial ecosystems. The chapter develops theoretical ideas that argue that differences in structure and organization, as well as in maturity and level of exploitation, have key roles in determining the consequences of interactions across boundaries separating different tesserae of ecological mosaics.

In this paper we use some examples to explore the Margalevian view of boundaries. We consider the difficulty of definition, examine field evidence of active processes, assess the direction of ecological influences, and whether the implied interactions among adjoining units may result in some degree of control on adjoining systems. We dare not follow Margalef into the more theoretical aspects, as we have some difficulty making concepts such as "ecological maturity" empirically operational and hence testable. Perhaps with Ramón's help we might make progress there, but as Margalef (1974) himself says, those may be "tareas del mañana".

Below we show examples of cross-boundary exchanges of water and dissolved substances, partic- 


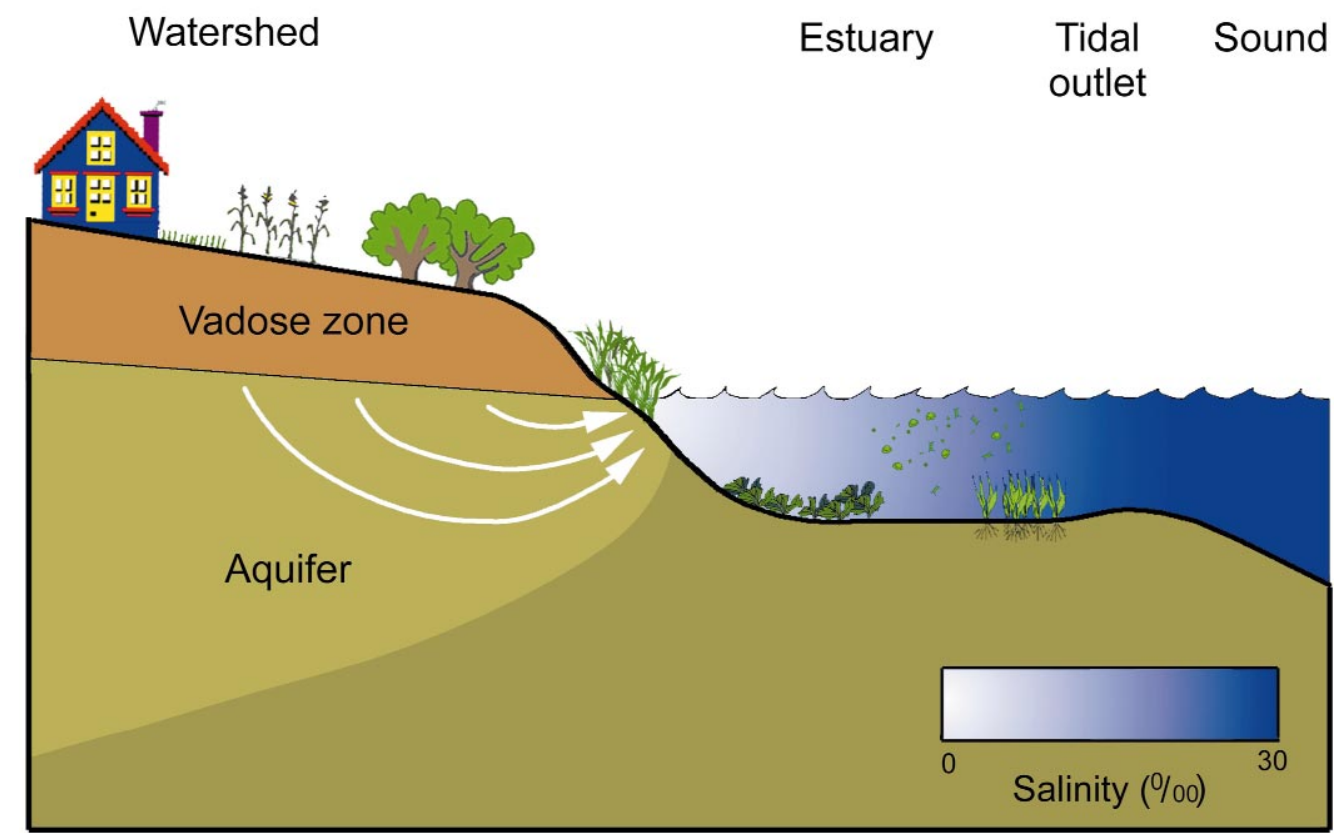

FIG. 1. - Sketch of the coupled land/estuarine tesserae found in the Waquoit Bay estuarine system. Land covers include residential, agricultural, and natural vegetation. Salt marshes are interposed between land and the receiving estuary. In this glacial terrain, precipitation percolates through soils and the unsaturated vadose zone (tan color), to reach the water table and the aquifer (light green), where it then moves as fresh groundwater (white arrows) toward the estuary, floating over the saline water (darker green) that fills pore spaces under the estuary, and flows into the estuary at the seepage face. Estuarine salinity is identified by intensity of blue color. In the estuary, there are phytoplankton, macroalgae, and seagrasses that contribute to primary production. The estuary exchanges water with the deeper Vineyard Sound, which contributes saltier water to mix with fresh groundwater derived from precipitation and groundwater flow.

ulate materials, and faunal elements, and of controls exerted in the coupled ecological units by these exchanges. We use mainly -but not exclusivelyexamples from coastal watersheds and estuaries.

\section{BOUNDARIES IN A COASTAL SYSTEM}

Most of the examples of boundaries, adjacent ecological units, and interactions among these units that we will discuss come from coastal watershed/estuarine systems in Cape Cod, Massachussetts, USA (Fig. 1). In these systems the watersheds contributing freshwater and solutes to the estuaries are covered by parcels of residential land use, agriculture, and forests. Because the glacialderived terrain is unconsolidated sands and gravel, precipitation percolates into soils, crosses the unsaturated vadose zone, and moves down-gradient through the aquifer toward the receiving estuarine waters. Near the seepage face, where fresh groundwater discharges, there is often a fringe of salt marsh. This strip of coastal wetland (replaced in the tropics by mangrove swamps) is characteristically interposed between land and sea.

Within the estuary part of the system there are three major types of producers: phytoplankton, macroalgae, and seagrasses (Fig. 1). The water within the estuary system is fresher near land, and becomes mixed by tidal exchanges and estuarine circulation via tidal outlets connecting to deeper marine waters (Fig. 1).

Some ecological boundaries in Fig. 1 are clearly demarcated. For example, the boundary represented by the watershed surface is clearly definable. The relevance of this boundary to the rest of our studies is that throughputs to down-gradient components of the coupled land/water system are significantly affected by the land use mosaic on the watershed surface. Other boundaries in Fig. 1 are less easily defined. Under the watershed surface there is an unsaturated vadose zone. We could consider this zone as a boundary itself or a separate ecological unit, depending on the spatial scales we might prefer. Where the sediment pore spaces become saturated by freshwater there is another apparently evident boundary, the water table. It turns out, however, as we discuss below, that the bound might not really be only the water table itself, but might also include the upper layers of groundwater within the aquifer.

The fringe of salt marsh interposed between land and the estuary could also be thought of as a separate ecological tessera or as a boundary (Fig. 1). 
Moreover, because of the excursion of tidal water in and out of the intertidal wetlands, and the fractal sinuosity of wetland vegetation zones, the notion of a boundary becomes unclear for coastal wetlands. Do we take the edge of vegetated marsh as the boundary, or do we consider the entire horizontal extent of wetlands as the bound? In addition, there are distinctive vegetation zones within the vegetation of salt marshes, each with their own ecotones, as well as marked spatial patchiness (Valiela et al., 1985) so that definition of boundaries is a challenging task. The tidal outlets that connect the estuary to deeper waters make up another possible boundary (Fig. 1). With tidally-driven mixing, again there is an issue of scale of definition of the boundary. For example, we might think of the entire range over which salinity changes from fresh to seawater across the estuary as the bound (Fig. 1). Alternatively, we might more narrowly choose to conceive of the outlets to deeper water as the bound. All these definitions will be to an extent arbitrary, and subject to effects of scale, as long ago noted by Slobodkin (1964).

As Margalef (1974) concludes, the concept of boundaries, though at first might appear as a clear idea, is less evident in actual field situations. It therefore seems more useful and practical to be less concerned with defining bounds or ecotones, and instead focus on the exchanges among adjoining tesserae, without strictly defining the nature of the bounds.

\section{EXCHANGES AND INTERACTIONS ACROSS BOUNDARIES}

Water is by far the major motive force underlying exchanges across the various boundaries and tesserae defined in Fig. 1. Water transports solutes, particles, and organisms. To a much lesser extent, motile organisms may add to the exchanges, and gaseous and aerosol transport may also take place.

\section{Transport by water}

Rates of nutrient transport through the watershed surface depend on the mosaic of land use. Interception of nutrients within each type of land use tessera differs (Johnes, 1996; Valiela et al., 1997), so that nitrogen loads from the entire watershed mosaic depend on the relative areas of different land uses within the watershed. We have been primarily concerned with nitrogen because it is the critical ele-

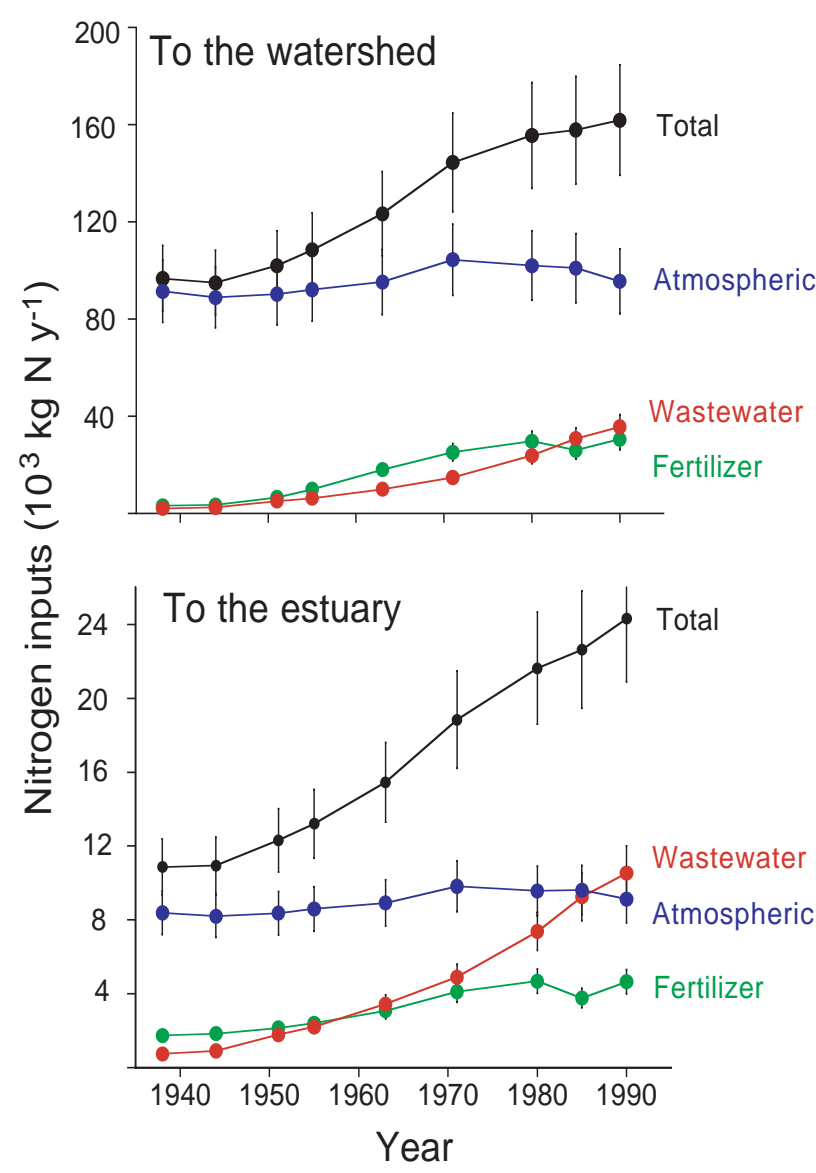

FIG. 2. - Estimates of land-derived nitrogen loads to the Waquoit Bay watershed surface (top panel), and to the estuary (bottom panel). Loads from wastewater (red), atmospheric (blue), and fertilizer (green) sources were estimated based on changes in land use from 1938 to present. Total loads shown in black. From Bowen and Valiela (2001a).

ment that limits primary production, and hence eutrophication of coastal waters (Nixon, 1995). We find that in the watersheds we have studied -where there is still a considerable area of natural vegetation- atmospheric deposition provides more than half the load to the watershed surface (Table 1). Because of the differential loss rates suffered by the nitrogen from atmospheric, fertilizer, and wastewater sources, wastewater becomes the dominant source of $\mathrm{N}$ to the receiving estuary systems. Passage through these boundaries and ecological units therefore substantially changes the relative magnitude of the different sources of nitrogen entering the receiving systems.

We applied calculations and models (Valiela et al., 1997; Bowen and Valiela, 2001a,b) to extrapolate nitrogen loading estimates back through recent decades (Fig. 2). The loads to the watershed of Waquoit Bay have increased since mid-20 $0^{\text {th }}$ century, largely because of increases in wastewater nitrogen, even though the major input has remained that of 
TABLE 1. - Nitrogen loading from atmosphere, fertilizers, and wastewater to the surface of the watershed of Waquoit Bay, losses during passage through the watershed/aquifer systems, and partition of the N loads received by the estuarine systems. From Valiela et al. (1997).

\begin{tabular}{lccc}
\hline Source of nitrogen & $\%$ of N load to watershed & $\begin{array}{c}\% \text { of N input lost within the } \\
\text { watershed/aquifer systems }\end{array}$ \\
\hline Atmospheric deposition & 56 & 90 & 67 \\
Fertilizer use & 16 & 78 & 17 \\
Wastewater disposal & 28 & 81 & 53 \\
Total & 100 & 100 \\
\hline
\end{tabular}

atmospheric deposition (Fig. 2 top). Loads to receiving waters (Fig. 2 bottom) have also increased across the decades, but have been considerably lower than to the watershed, evidence of significant within-watershed retention. Wastewater nitrogen has increased sufficiently to become the major $\mathrm{N}$ source to the estuaries.

We can further document the predominant role of wastewater nitrogen delivery by use of stable isotopic signatures (McClelland et al., 1997; McClelland and Valiela, 1998). Nitrate derived from wastewater tends to show heavier $\left({ }^{15} \mathrm{~N}\right.$ signatures; the greater the proportion of wastewater in that total land-derived nitrogen load from a watershed, the heavier the signature in the fresh groundwater leaving the aquifer and entering a receiving estuary; this heavier signature can be traced throughout the estuarine food web (McClelland et al., 1997).

The losses of ecologically important nutrients incurred during transport through watershed, vadose zone, and aquifer are not constants, but depend on features of the ecological units and boundaries traversed. For instance, throughput of dissolved organic carbon (Pabich et al., in press), of nitrate (Pabich et al., submitted), of ammonium and of dissolved organic nitrogen (Kroeger et al., in prep.) to the groundwater below depends on depth of the vadose zone and on the distance traversed within the aquifer. The pattern in general is that lower concentrations of nutrients are found near the water table under thicker unsaturated vadose zones, and that concentrations of nutrients are dramatically attenuated by passage through aquifers.

Differences in nutrient throughput created by differences in vadose zone thickness have consequences for adjoining down-gradient ecological units. One example of these inter-unit couplings is provided by a consideration of vertical nutrient profiles within the groundwater below the vadose zone (Fig. 3). Where depths of vadose zones above were shallow (Fig. 3 top), there were high concentrations of DOC near the water table. The high concentrations decreased sharply with depth in the aquifer: there was more than an order of magnitude lowering of concentrations by $1 \mathrm{~m}$ in depth. In contrast, where the vadose zone was thick (Fig. 3 bottom), DOC

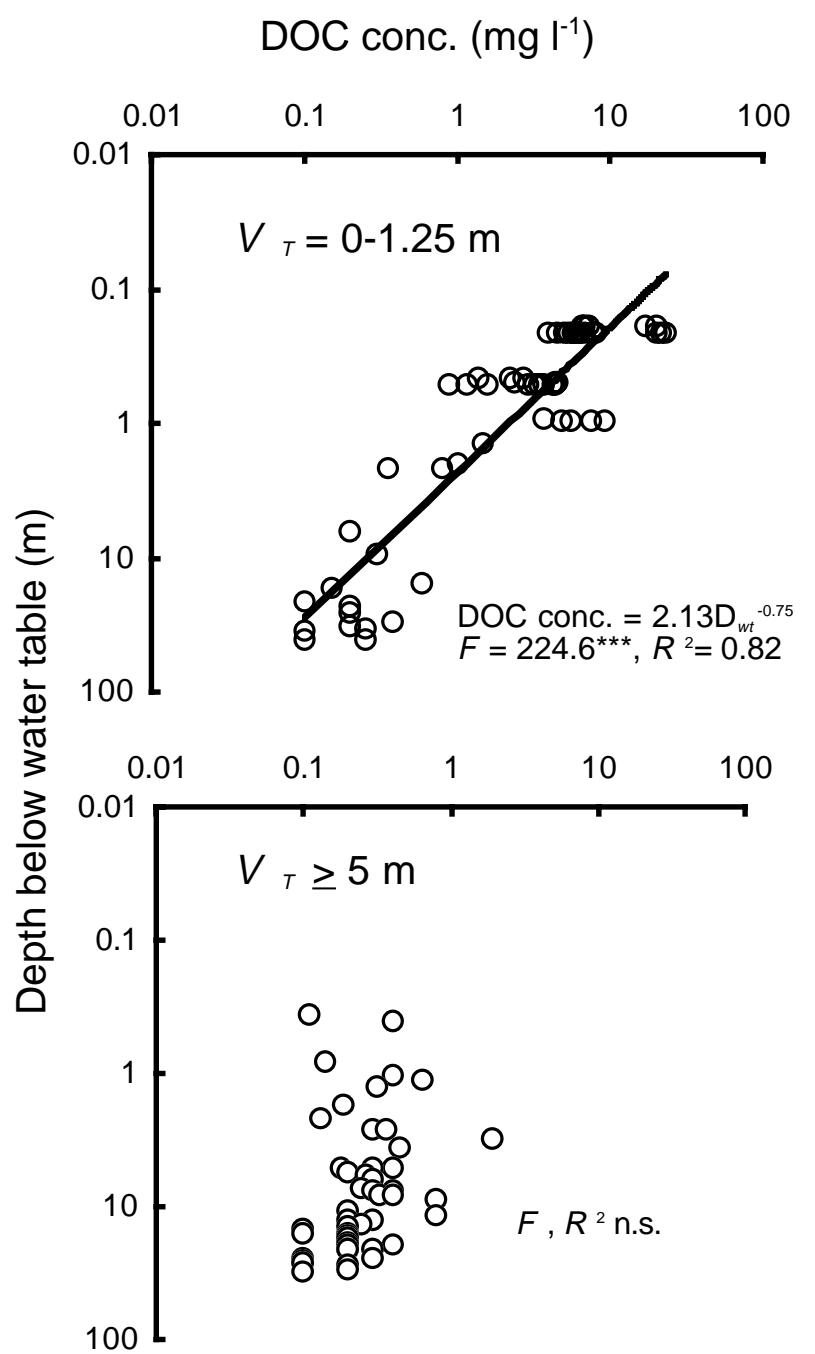

FIG. 3. - Vertical profiles of concentrations of dissolved organic carbon in groundwater beneath the Waquoit Bay watershed surface. Top panel for sites where depth of the vadose zone $\left(V_{T}\right)$ was between 0 to $1.25 \mathrm{~m}$, bottom panel for sites where $V_{T}$ was greater than 5 m. Adapted from Pabich et al. (2001). 

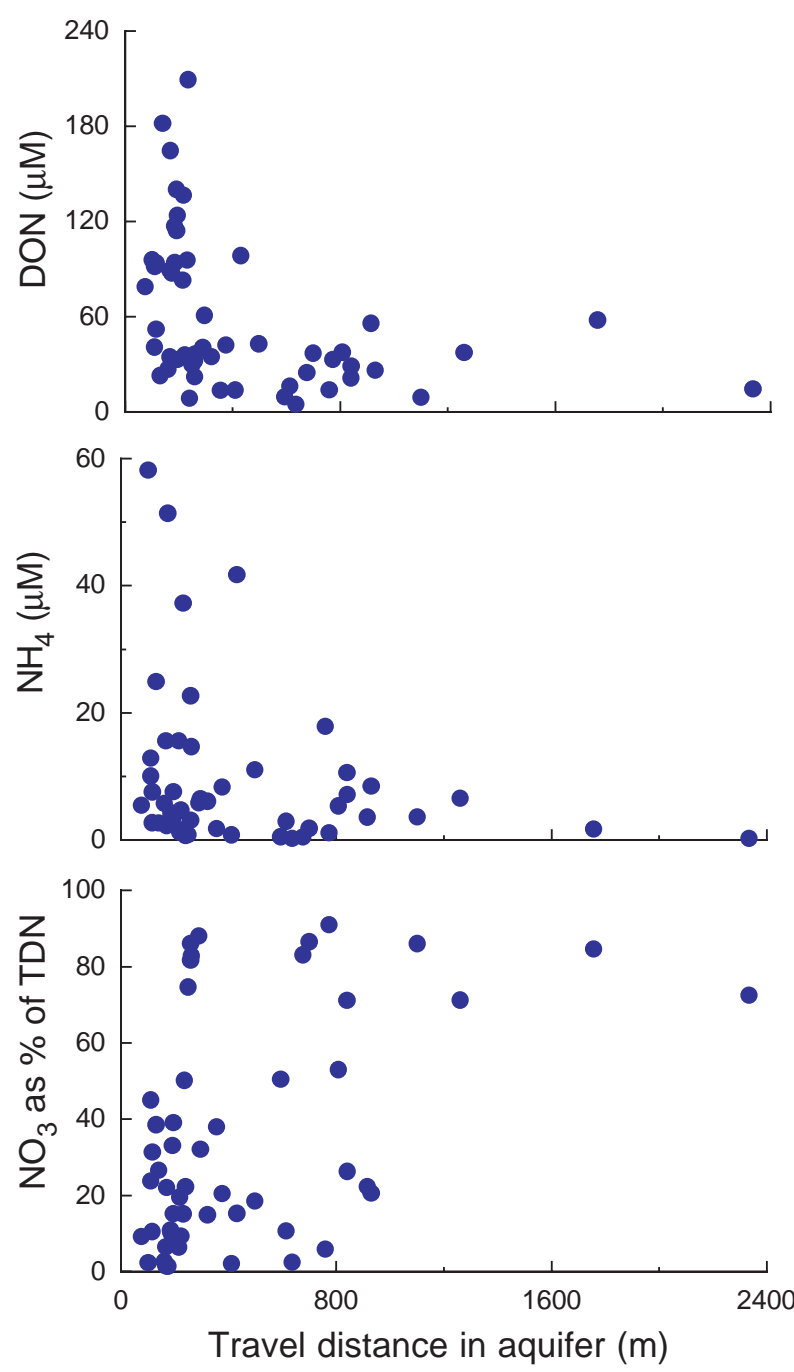

FIG. 4. - Concentration of dissolved organic nitrogen (top) and ammonium (middle) in groundwater of the aquifer under the Waquoit Bay watershed versus the horizontal distance the water has traveled within the aquifer. Nitrate, expressed as percentage of the total nitrogen concentration, plotted vs. the travel distance in the aquifer (bottom). Data of Kevin Kroeger.

concentrations did not reach high values, and there was no significant loss of DOC with depth. We can also show similar profiles of dissolved organic nitrogen, nitrate, and ammonium (Pabich et al., submitted; Kroeger, in prep.).

Results such as shown in Fig. 3 show first, that a relatively thin layer of groundwater just below the watertable can be a boundary (or unit?) where there is intense microbial activity. Second, that the rate of loss of DOC (or of other nutrients) in this thin layer depends on rate of delivery from the vadose zone above (Pabich et al., in press). Third, the nature of the vadose zone matters greatly: thicker vadose zones intercept sufficient DOC (and other compounds) to uncouple rates of microbial activity in the upper layers of groundwater from influences from above. Thus, properties of one ecological unit, in this case the depth of the vadose zone, greatly affect the functioning of the adjoining ecological unit just below the water table.

Passage of materials from the watershed surface through vadose zones or aquifers may alter not only the amounts but also the composition of the materials transferred from one ecological unit to the next (Fig. 4). For example, considerable quantities of reduced nitrogen compounds $\left(\mathrm{DON}\right.$ and $\mathrm{NH}_{4}$ ) are transported into aquifers. During passage through the aquifer both adsorption and microbial mineralization of DON (Fig. 4 top) and adsorption and nitrification of $\mathrm{NH}_{4}$ to $\mathrm{NO}_{3}$ (Fig. 4 middle) takes place. Nitrate concentrations are also attenuated during passage through aquifers (Pabich et al., submitted), but nitrate is also generated during transport, making the down-gradient trend less evident. The lowering of concentrations of reduced nitrogen compounds is more marked, and hence the proportion of nitrate in the total load increases as the distance traveled within the aquifer increases (Fig. 4 bottom). The net result of differences in sources and transformations during transport is that the mix of reduced and oxidized $\mathrm{N}$ that is eventually exported from the aquifer to receiving estuaries varies depending on features within the donor units upgradient. These differences in composition then could affect quite different ecological elements within receiving estuaries. Heterotrophs might respond to DOC and DON supply, autotrophs to nitrate supply.

In spite of losses of nitrogen within soils, vadose zone, and aquifer, some fraction of land-derived nitrogen reaches the seepage face. The magnitude of the fraction depends significantly on the disposition of land use tesserae on the watershed surface, as we concluded from discussion of the historical reconstruction of nitrogen loads (Fig. 2). Thus, human activity on the watershed surface reaches across soil, vadose zone, and aquifer, and significantly alters the variable-nitrogen loading-we think might drive ecological change in the receiving estuaries. The couplings among adjacent ecological units might therefore reach across several such units, as if the units were connected in series.

In support of the above assertion we can marshal considerable evidence that urbanization of the watersheds during recent decades (Fig. 2) has increased land-derived nitrogen loads, and has been responsible for a major re-shuffle of producer ecology within the estuary complex in Waquoit Bay. Phytoplankton 
biomass and production (Fig. 5), have increased in estuaries that receive higher land-derived nitrogen loads (Fig. 5 top), and the increased phytoplankton production is related to the concentration of available nitrogen (Fig. 5 bottom), which in turn is related to the magnitude of the load received from land (Valiela et al., 2000a). Similarly, macroalgal biomass and production have also increased (Valiela et al., 1992; 2000b; Peckol et al., 1994; Stieve et al., submitted). In contrast, seagrass biomass and production, as well as areal extent of seagrass meadows, have decreased sharply (Valiela et al., 1992; 2000b; Short and Burdick, 1996). The high sensitivity of seagrasses to nitrogen loads, in spite of their being light-limited (Dennison and Alberte, 1982), has been discussed (Sand-Jensen and Borum, 1991; Duarte, 1995; Valiela and Cole, in press). Shading by increased phytoplankton and macroalgal biomass that follows increased nitrogen supplies sharply lowers seagrass activity (Hauxwell et al., 2001). In general, seagrasses decline sharply in response to increases in nitrogen loads. Both seagrass production (Fig. 6 top), and seagrass meadow habitat area (Fig. 6 bottom) show a significant decreasing trend as $\mathrm{N}$ loads increase, so
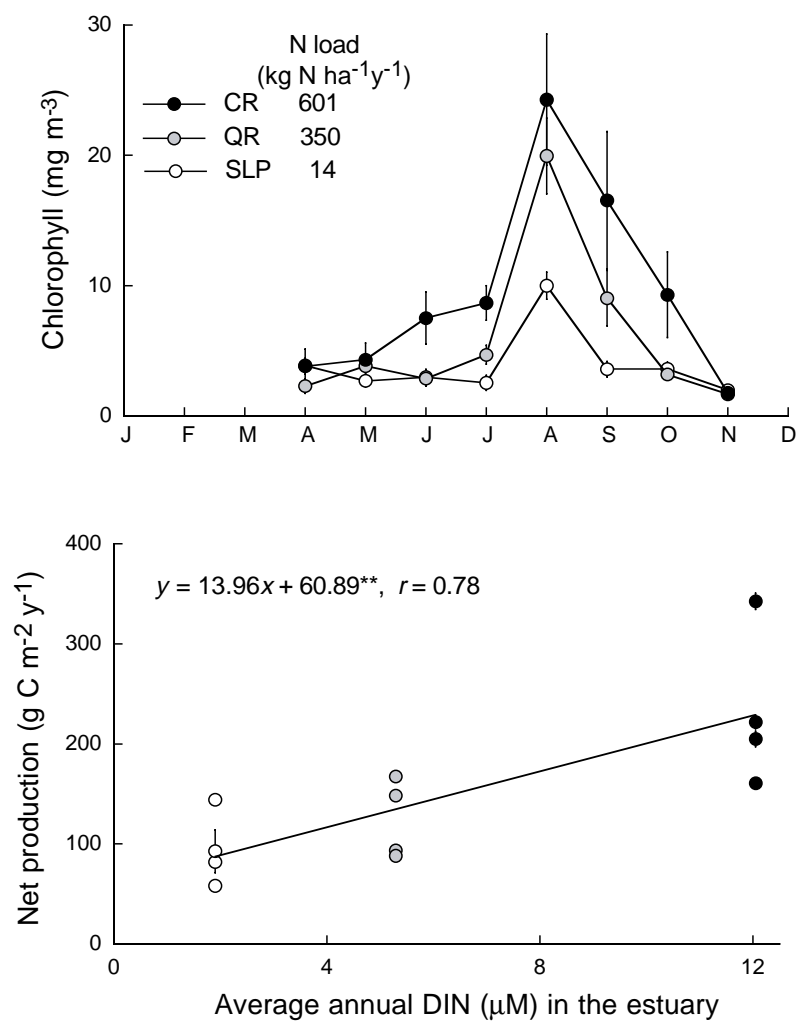

FIG. 5. - Chlorophyll concentration in three estuaries of the Waquoit Bay estuarine system across the year (top). Annual phytoplankton production for the three estuaries of the top panel, plotted vs. the annual nitrogen load received from the watersheds (bottom) Adapted from Foreman et al. (submitted).

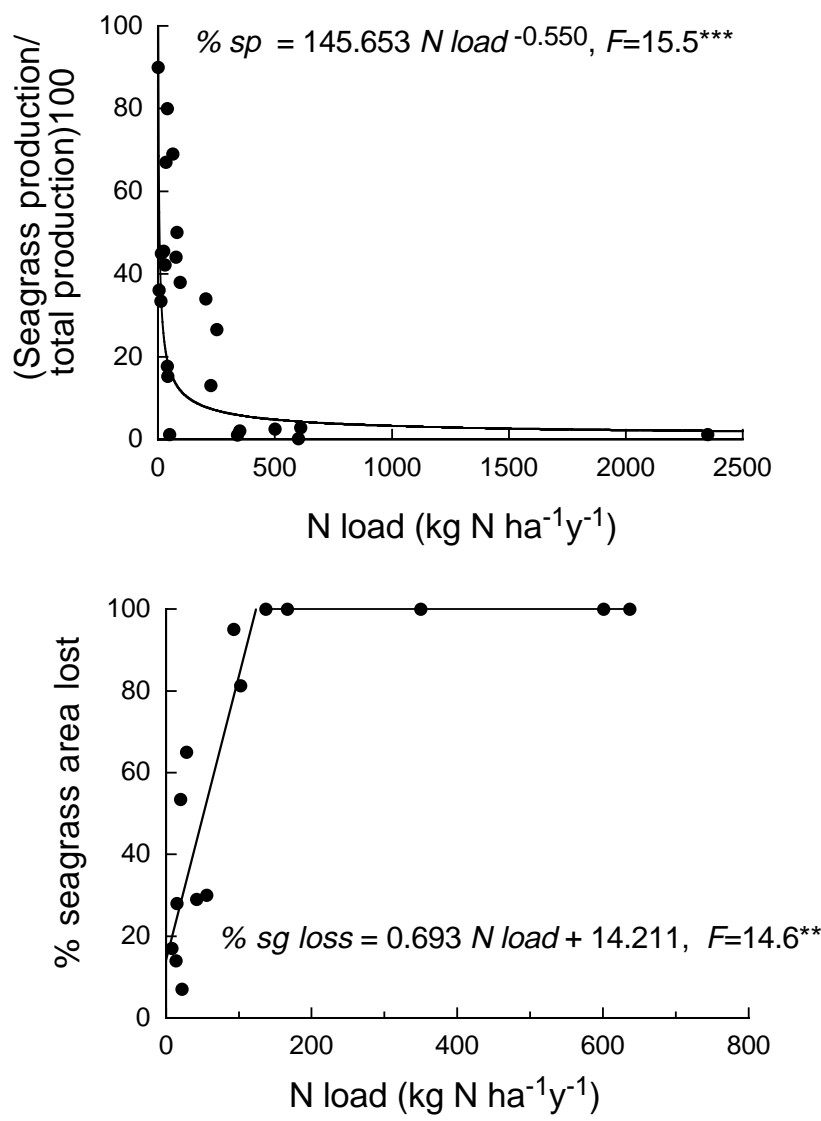

FIG. 6. - Top: Seagrass production as $\%$ of total production versus land-derived nitrogen load to the estuary. Bottom: Percentage of area of seagrass habitat lost (over last 10 to 30 years) in several estuaries, plotted versus the corresponding land-derived nitrogen load. From Valiela and Cole (in press).

that beyond $100-200 \mathrm{~kg} \mathrm{~N} \mathrm{ha}^{-1} \mathrm{yr}^{-1}$, these environments disappear.

The effects of land-derived nitrogen load on estuarine producers are summarized in Fig. 7, which shows that the relative contribution to total estuarine production carried out by seagrasses sharply decreases as $\mathrm{N}$ loads increase (largely due to the changes in the land use mosaic on the watershed surface) and is replaced by phytoplankton and macroalgal production. The effects of water residence times on these relationships is discussed below.

In the discussion so far we ignored one other bound inserted between land and sea, the salt marsh fringe (Fig. 1). This may be another boundary that is hard to define as a border, for it does vary greatly in dimension and distribution along coastlines. As a simplification, however, we can consider the relative proportion of salt marsh area in different estuaries to make another point: that because of their position between land and estuary, as well as their high rates of denitrification and burial of nitrogen, salt marshes may provide substantial interception of land-derived nitrogen. If indeed 


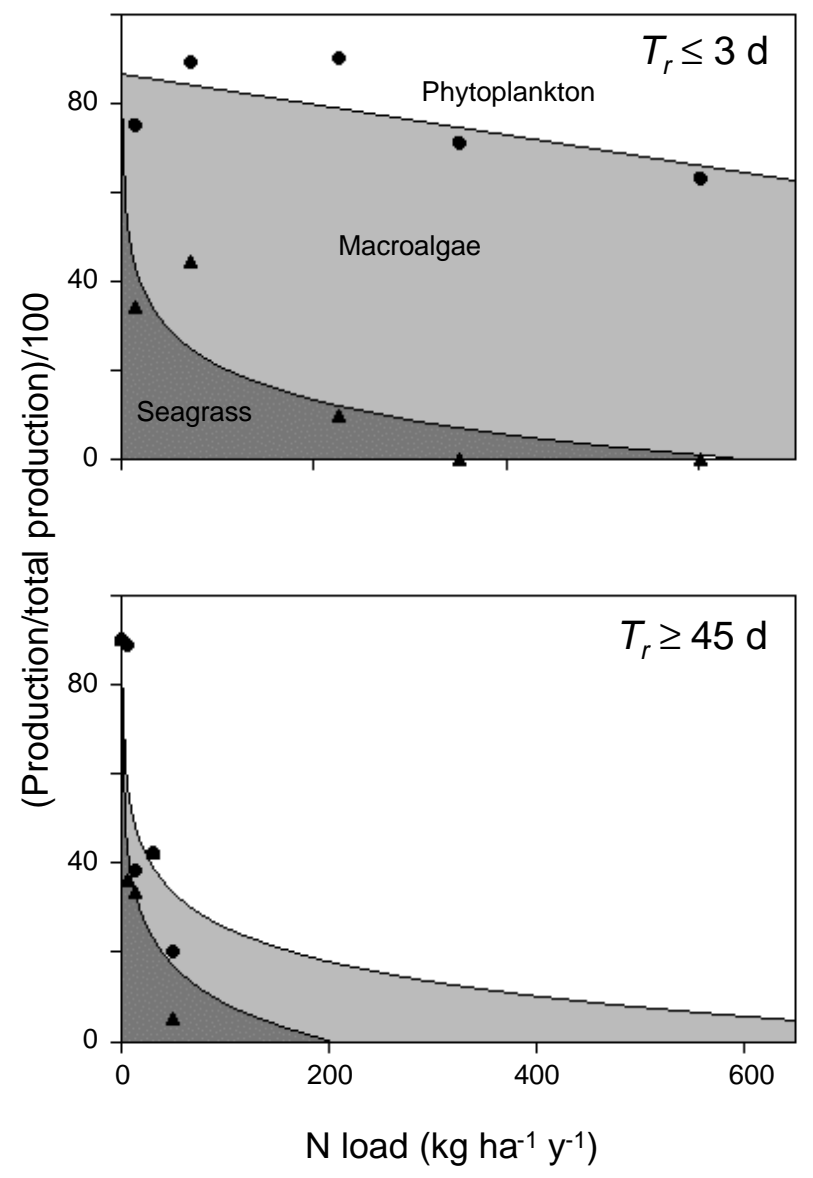

FIG. 7. - Proportion of primary production by phytoplankton, macroalgae, and seagrasses in estuaries subject to different landderived nitrogen loads. Top panel contains information for estuaries whose water residence times $\left(T_{r}\right)$ are less than $3 \mathrm{~d}$, bottom panel for estuaries with $T_{r}$ greater than 45 d. From Valiela et al. (2000b).

nitrogen loads from land are responsible for loss of eelgrass meadows, interception of land-derived nitrogen in coastal wetlands might be interpreted as a protective "subsidy" furnished by salt marshes (and mangrove swamps) to eelgrass meadows.

We compiled published data on seagrass production (Fig. 8 top) and loss of seagrass habitat (Fig. 8 bottom) and wetland areas in the same estuaries (Valiela and Cole, in press). The results of the compilation show that the larger the area of salt marsh or mangrove swamp, the greater the production by seagrasses (Fig. 8 top), and the smaller the loss of seagrass meadows that occurred as nitrogen loads increased (Fig. 8 bottom). Thus, whether we think of the coastal wetland as an active bound, an ecological tessera, or as a "third player" of game theory, as suggested by Margalef (1974), the presence of this coastal unit alters the inputs from the watersheds sufficiently to make a difference to the receiving adjoining seagrass meadows.
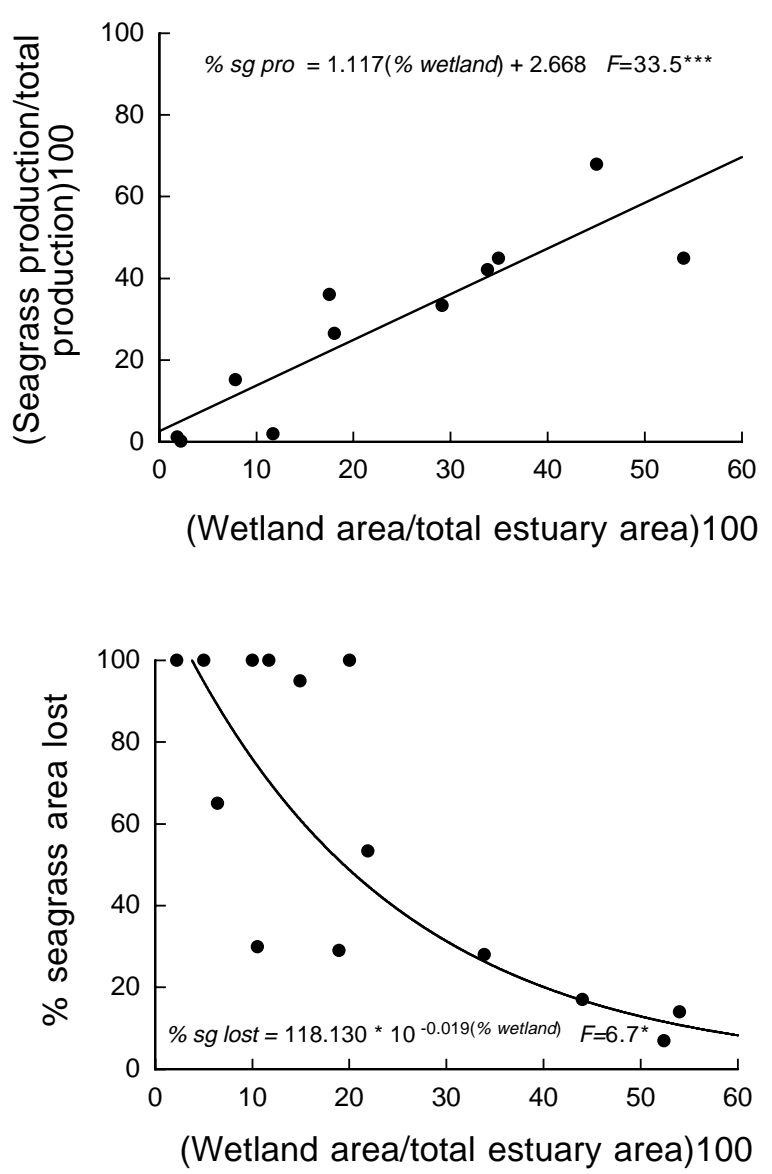

FIG. 8. - Top: Seagrass production expressed as a $\%$ of total production in many estuaries, plotted versus the area of fringing wetland expressed as a \% of total estuary area. Bottom: \% of area of seagrass habitat lost (over last 10 to 30 years) plotted versus the \% of area of the estuary made up by fringing wetland. From Valiela and Cole (in press).

The quantitative relationships of land-derived loads, nitrogen interception in coastal wetlands, and susceptibility of seagrass meadows remain to be defined, but it is clear that adjoining parcels of landand waterscapes are not isolated units. Rather, recognizably different ecosystems are coupled by transports from one tessera to the next. In our example, transport of land derived-nitrogen can influence seagrass meadows, but that influence is mediated -within a certain range of values of the transport rate- by the sequestration of nitrogen in coastal wetlands interposed between land and estuary. Where we see productive seagrass meadows (Fig. 9), we may appreciate that the nearby salt marshes might be providing an important subsidy by intercepting land-derived nitrogen. This finding has basic interest in terms of controls of adjoining ecological parcels. There are also applied aspects, in that coastal development increases nitrogen loads from land to estuaries, and management of such loads should consider 


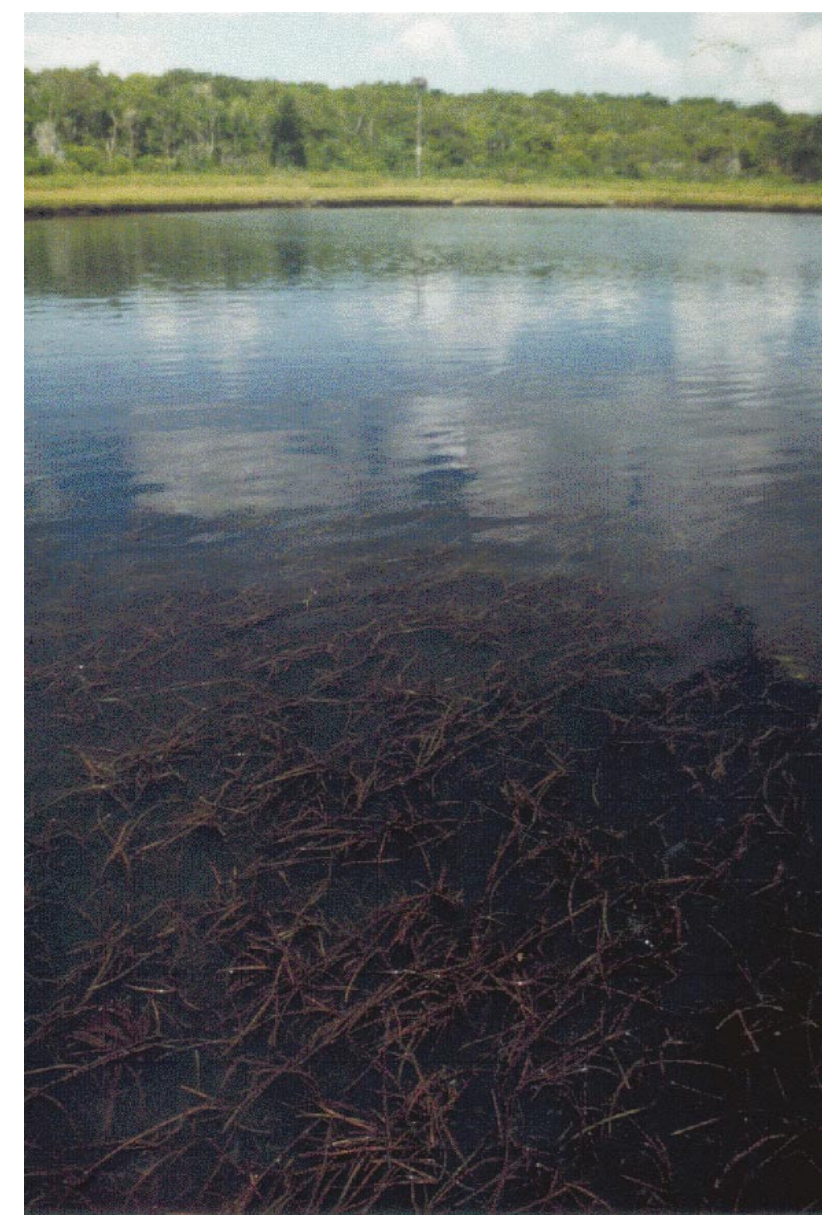

FIG. 9. - Photo of a vigorous seagrass (Zostera marina) meadow in Waquoit Bay located off a salt marsh that intercepts land-derived nutrients. Photo by J. Hauxwell.

the importance of coastal wetlands as a mediator of the effects of land-derived eutrophication.

The outer bounds of the watershed/estuary system, the tidal outlets to deeper water, allow active mixing and transport in and out of coastal estuaries (Fig. 1). In the vast majority of cases, nutrient-richer estuarine water is mixed with nutrient-poorer coastal water, hence diluting the concentrations. The rates of this dilution are set in part by the residence time of water within the estuaries. The shorter the residence time, the more effective the dilution. Inherent in this simplified idea is that the shorter the residence time, the greater the export of nitrogen to the deeper water beyond the boundary (Howarth et al., 1996). We could conceive of water residence time as a coupling/decoupling mechanism among adjoining systems. Where water residence times within estuaries is short, the land-derived materials transported through an estuary are shunted effectively through the estuarine complex, and the exported materials exert their influence most strongly on the ecology of the deeper coastal waters. Where water residence times are long, the transformations and sequestration within the estuarine complex may be more influential, and to some undefined extent may uncouple the link between watersheds and the deeper waters offshore. This topic merits future attempts at quantification.

Any student of marine data has perceived that there are strong gradients in solutes and particles from the shore to deeper waters of the sea. From this it is logical to suppose that the major sources of these substances are from land to sea. In fact, coastal estuaries, particularly those with wetlands, have for some decades been considered to supply materials that subsidize the metabolism of deeper coastal waters (Teal, 1962; Odum, 1971). Reviews of published data suggest that the majority of salt marshdominated estuaries export ammonium, dissolved organic nitrogen, particulate organic nitrogen, total nitrogen, dissolved organic carbon, particulate organic carbon, and total carbon (Table 2). In contrast, only a minority of such coastal systems export nitrate to deeper waters. Rather, nitrate may be denitrified within the estuaries and lost as $\mathrm{N}_{2}$. The propensity to export energy rich materials is more widespread in more "mature" marsh estuaries (Table 2). Maturity here refers to the degree to which the passage of time has allowed accumulation of sediments within the system, and hence has led to reduction of open water area, and development of tortuous channels.

Mass balance studies in a salt marsh-dominated estuary in Cape Cod showed that, as a whole, the system transformed oxidized nitrogen inputs into more energy-rich reduced nitrogen and exported a portion of the inputs as dissolved and particulate organic nitrogen and as ammonium (Valiela and Teal, 1979). Such exports -another example of the changes in composition mentioned earlier when discussing aquifers- thus furnish energy-laden nitrogen supplies to nitrogen and energy-poorer deeper waters. The quantitative importance of exports to deeper waters was demonstrated by Hopkinson (1985), who measured metabolism of coastal waters off salt marsh estuaries and concluded that organic matter export from the fringing salt marshes is the most reasonable source for the organic matter that supports a significant fraction of the metabolism of the coastal water column.

So far we have focused on down-gradient transports among adjoining ecological tessera, that is watershed to aquifer, to streams, to estuary, and to 
TABLE 2. - Summary of studies of exports and imports of ammonium $\left(\mathrm{NH}_{4}\right)$, nitrate $\left(\mathrm{NO}_{3}\right)$, dissolved organic nitrogen (DON), particulate nitrogen (PON), total nitrogen (TN), dissolved organic carbon (DOC), particulate organic carbon (POC), and total carbon (TC) from salt marshes to coastal waters ${ }^{1}$. This table is from Valiela and Cole (2000). E: export, I: import, O: no net transport.

\begin{tabular}{|c|c|c|c|c|c|c|c|c|}
\hline Estuary & $\mathrm{NH}_{4}$ & $\mathrm{NO}_{3}$ & DON & PON & $\mathrm{TN}$ & DOC & POC & TC \\
\hline & \multicolumn{8}{|c|}{ Young marshes } \\
\hline Canary Creek, DE & I & I & $\mathrm{E}$ & $\mathrm{E}$ & $\mathrm{E}$ & $\mathrm{E}$ & $\mathrm{E}$ & $\mathrm{E}$ \\
\hline Crommet Creek, NH & I & $\mathrm{O}$ & & & & & & \\
\hline Ems-Dollard Marsh, Netherlands & & & & & & $\mathrm{E}$ & I & I \\
\hline Flax Pond, NY & $\mathrm{E}$ & I & & & & $\mathrm{O}$ & I & I \\
\hline Sapelo Island, GA & $\mathrm{O}$ & $\mathrm{O}$ & $\mathrm{E}$ & I & & $\mathrm{E}$ & I & \\
\hline \multirow[t]{2}{*}{ Stroodorpe Marsh, Netherlands } & & & & $\mathrm{I}$ & & & I & \\
\hline & \multicolumn{8}{|c|}{ Mature marshes } \\
\hline Barataria Bay, LA & & & & & & $\mathrm{E}$ & $\mathrm{E}$ & $\mathrm{E}$ \\
\hline Bly Creek, SC & & & & & & $\mathrm{E}$ & $\mathrm{I}$ & $\mathrm{E}$ \\
\hline Branford Marsh, CT & $\mathrm{E}$ & I & & & & & & \\
\hline Carter Creek, VA & I & I & $\mathrm{E}$ & I & $\mathrm{E}$ & $\mathrm{E}$ & E & $\mathrm{E}$ \\
\hline Coon Creek, TX & & & & & & $\mathrm{E}$ & $\mathrm{O}$ & $\mathrm{E}$ \\
\hline Dill Creek, SC & & & & & & & $\mathrm{E}$ & \\
\hline Gotts' Creek. MD & $\mathrm{E}$ & $\mathrm{E}$ & $\mathrm{E}$ & $\mathrm{E}$ & & & $\mathrm{E}$ & \\
\hline Great Sippewissett Marsh, MA & $\mathrm{E}$ & $\mathrm{E}$ & $\mathrm{E}$ & $\mathrm{E}$ & $\mathrm{E}$ & & $\mathrm{E}$ & $\mathrm{E}$ \\
\hline Kariega Marsh, S. Africa & & & & & & $\mathrm{E}$ & $\mathrm{O}$ & $\mathrm{E}$ \\
\hline North Inlet, SC & & & & & & $\mathrm{E}$ & $\mathrm{E}$ & $\mathrm{E}$ \\
\hline Tijuana Estuary, CA & $\mathrm{E}$ & $\mathrm{E}$ & & $\mathrm{E}$ & & & $\mathrm{E}$ & \\
\hline (two marshes) & $\mathrm{E}$ & $\mathrm{E}$ & & $\mathrm{E}$ & & & $\mathrm{E}$ & \\
\hline \multirow[t]{2}{*}{ Ware Creek, VA } & $\mathrm{E}$ & $\mathrm{I}$ & $\mathrm{E}$ & $\mathrm{E}$ & $\mathrm{E}$ & $\mathrm{E}$ & $\mathrm{E}$ & $\mathrm{E}$ \\
\hline & \multicolumn{8}{|c|}{ Percent of marshes that export materials } \\
\hline "young" marshes: & 25 & 0 & 100 & 33 & 100 & 75 & 20 & 33 \\
\hline "mature" marshes: & 86 & 57 & 100 & 83 & 100 & 100 & 75 & 100 \\
\hline All marshes: & 64 & 36 & 100 & 67 & 100 & 91 & 59 & 82 \\
\hline
\end{tabular}

deeper coastal waters. There are some mechanisms that propel materials reciprocally, upgradient. One example is that during storms, aerosols and larger droplets of salt water are deposited on nearshore land surfaces. These deposits kill vegetation on land, and also the contained salt displaces ammonium adsorbed from soils nearshore. The ammonium then is free to move towards the receiving estuary. This aerosolbased leaching therefore alters nearshore vegetation as well as makes coastal soils poor in available nitrogen (Valiela et al., 1996; 1998). Mass balance calculations suggest, however, that the nitrogen transport involved in this leaching is orders of magnitude smaller than the other items in coastal nitrogen budgets. Similarly, in general tidal exports are considerably higher than tidal imports into estuaries.

\section{Organism exchanges}

\section{Indirect effects}

Water motions within estuaries may occur at different rates, and these differences, subsumed for convenience as water residence times $\left(T_{r}\right)$, might have important indirect consequences for the organisms within these systems. We compiled published values of $T_{r}$ for as many estuaries as possible, and found that the average, $T$, were surprisingly short (Fig. 10 top). The issue seems relevant even for fast-dividing small organisms such as phytoplankton (Vallino and Hopkinson, 1998). Modal division rates of marine and estuarine phytoplankton (Fig. 10 bottom) are $<1 \mathrm{~d}$; these are such that most phytoplankton would have insufficient time to divide and hence bloom within many estuaries. Tidal exchanges in such estuaries would sweep cells out to sea before blooms could be accomplished, clearly a paradoxical notion. In estuaries of Waquoit Bay, we clearly have estuary-specific responses of the phytoplankton to the nutrient regimes of the estuaries (Fig. 5), even though $T_{\mathrm{r}}$ are 1-2 d (our unpublished data). Nevertheless it appears that the short water residence times of Waquoit estuaries do manage to prevent phytoplankton from dominating the total production (Fig. 7 top), even at high nitrogen loads. In contrast, where water residence times were longer (Fig. 7 bottom), phytoplankton did become by far the dominant component of total estuarine production. 

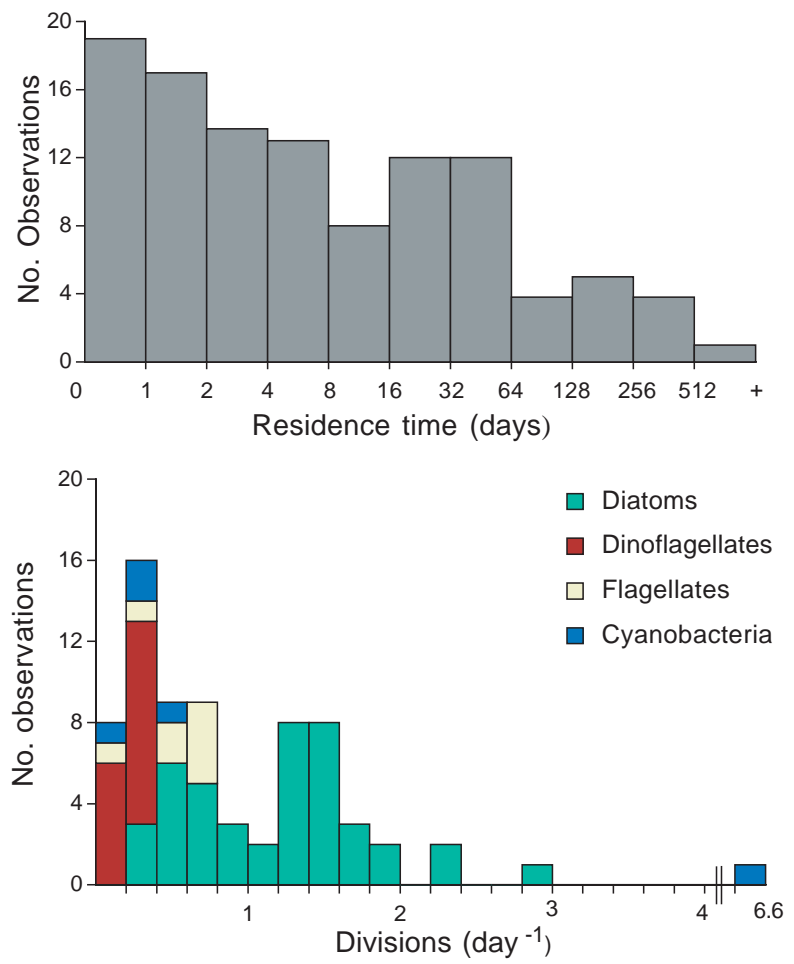

FIG. 10. - Top: Frequency distribution of values of estuarine water residence times. Bottom: Frequency distribution of division rates for a variety of phytoplankton taxa. Top and bottom compiled from the literature and included in Tomasky and Valiela (submitted).
The effects of $T_{\mathrm{r}}$ might be even more pronounced for organisms with longer generation times such as zooplankton. Pace et al. (1992) and others have pointed out that such $T_{r}$ might be so short that they affect the population dynamics of estuarine organisms. In Waquoit Bay estuaries, for example, there is evidence that female Acartia tonsa, the dominant copepod, clearly respond to the food abundance furnished by the phytoplankton that grow on the available nutrient supply within the specific estuary where we collected the copepods, as reflected in their egg production (Fig. 11 top). Thus, the copepods in each estuary are coupled to the ambient food supply conditions in each estuary. Nonetheless, this response does not translate into a parallel response of abundance: there were no significant differences in the numbers of copepods among estuaries, and the magnitude of the abundance was similar to that found in phytoplankton-poorer deeper water (Fig. 11 bottom) (Lawrence, 2000). We infer from these results that perhaps the short $T_{r}$ of Waquoit Bay estuaries uncouples the response of Acartia tonsa population abundance from control by food supply, even though the females clearly are laying eggs in proportion to within estuary food supply. Females
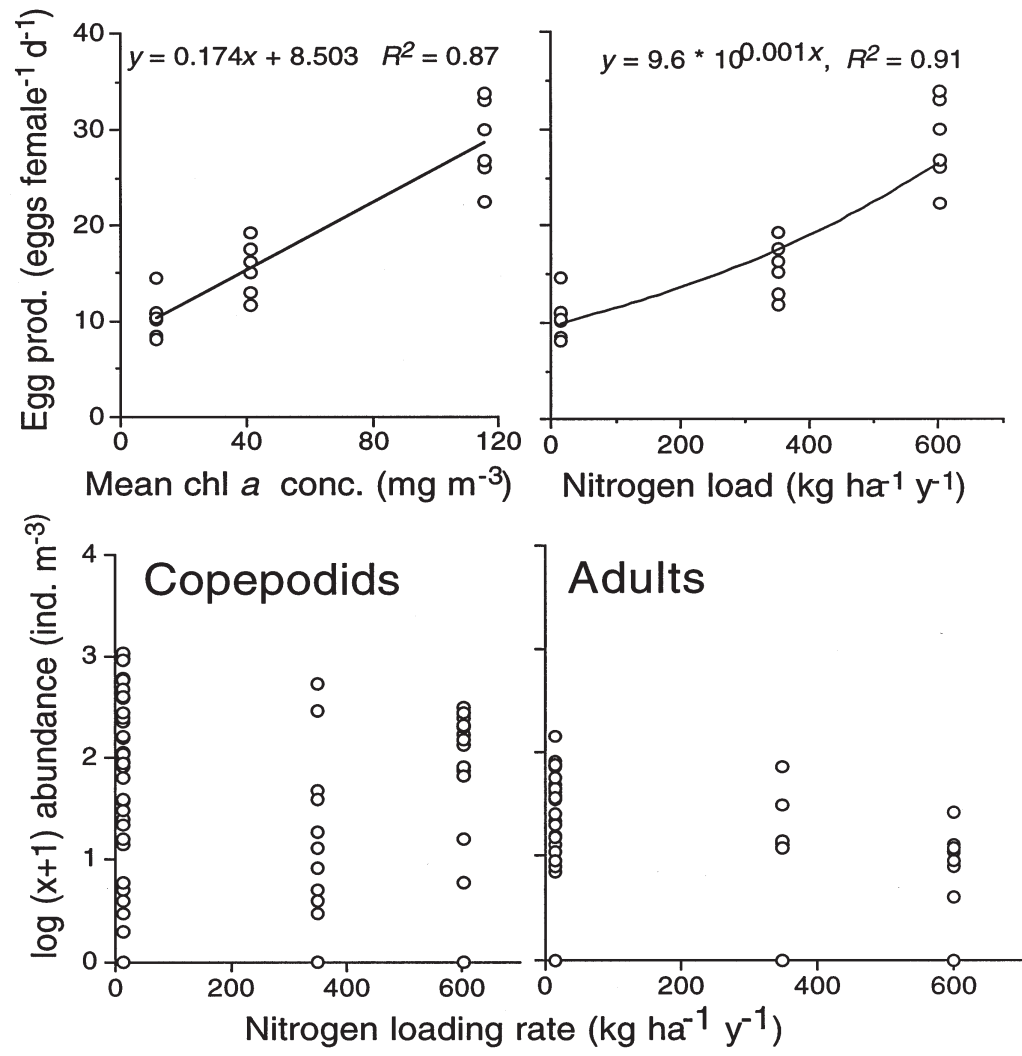

Fig. 11. - Top: Egg production by Acartia tonsa in Waquoit Bay estuaries relative to mean chlorophyll concentrations (left), and land-derived nitrogen load (right)(Cubbage et al., 1999). Bottom: Abundance of copepodids (left) and adults (right) of Acartia tonsa relative to land-derived nitrogen load to Waquoit Bay estuaries (Lawrence, 2000). 
TABLE 3. - Comparisons between species of fish resident in Great Sippewissett Marsh and species of fish whose adults live in deeper water, but whose young invade salt marsh estuaries. Results of paired $t$-test are non-significant (n. s.), significant at 0.05 (*), or highly significant $(* *)$. Data from Werme (1981).

\begin{tabular}{|c|c|c|c|}
\hline & Resident species ${ }^{\mathrm{a}}$ & Invader species ${ }^{\mathrm{b}}$ & Paired $t$-test \\
\hline Mean length of fish in marsh & $41 \pm 4$ & $59 \pm 9$ & n. s. \\
\hline Mean length of adults & $106 \pm 19$ & $422 \pm 121$ & $*$ \\
\hline$\%$ full guts & $26 \pm 4$ & $59 \pm 9$ & $* *$ \\
\hline$\%$ carnivory in diet & $48 \pm 13$ & $78 \pm 16^{c}$ & $* *$ \\
\hline Mouth gape & $1.9 \pm 0.3$ & $4 \pm 0.6$ & $* *$ \\
\hline No. fish/100 $\mathrm{m}$ of shoreline & $57 \pm 31$ & $0.8 \pm 0.3$ & $* *$ \\
\hline$\%$ growth/month & $18 \pm 4$ & $127 \pm 27$ & $* *$ \\
\hline
\end{tabular}

Resident species include Menidia menidia, Apeltes quadracus, Fundulus heteroclitus, Fundulus majalis, and Cyprindon variegatus.

' Invader species include Alosa psuedoharengus, Brevoortia tyrannus, Gasterosteus aculeatus. Tautoga onitis, Centropristes striatus, and Pseudopleuronectes americanus.

c $90 \%$ if Brevoortia tyrannus is excluded.

do produce more eggs, but the resulting young will be released in the deeper waters of Vineyard Sound, after the females that were feeding in the specific estuaries are swept out to sea.

\section{Direct effects}

It is well-known that estuaries are used by many organisms as nurseries where larvae and juvenile life stages of species found in deeper waters as adults find abundant food supplies and refuge. An example of these migrations can be found in the assemblage of fish that are often found in estuaries with associated salt marsh fringes (Werme, 1981) (Table 3). Within the estuary, the size of fish that reside in the estuary does not differ from that of the juvenile invader species whose adults live in deeper waters: there are disadvantages to having a larger size in these estuaries, because larger fish are readily eaten by the many top predators including herons, egrets, and other birds. Invader fish, however, have fuller guts, and are far more carnivorous than resident fish. The invaders manage this by taking advantage of their larger gape: although they have similar lengths, they have access to larger food items than the residents. This difference in gape derives from the simple allometric relationships of juveniles vs. adults vertebrates: young vertebrates have relatively larger heads than adults, and invaders are all juveniles. Hence invaders have larger heads and consequently, larger gape (Table 3). Feeding on larger prey places a bound on abundance of invaders, because, as is well known, larger prey are much less abundant than small prey. Hence, invaders are limited to much lower densities (Table 3). The benefit, and probably the evolutionary forcing towards invading estuaries, is made evident by the relative growth reported in Table 3. Invader species attain a growth rate an order of magnitude larger than resident species. Thus, though obligatorily rarer, invaders from another adjoining environment can achieve relatively fast growth rates in salt marsh estuaries.

The importance of coastal wetlands as nurseries for coastal populations can also be of economic importance. Shrimp yields in the coast of the Gulf of Mexico, for example are proportional to the area of coastal wetland landward of the harvest area (Fig. 12 top). In recent decades the yield of shrimp from
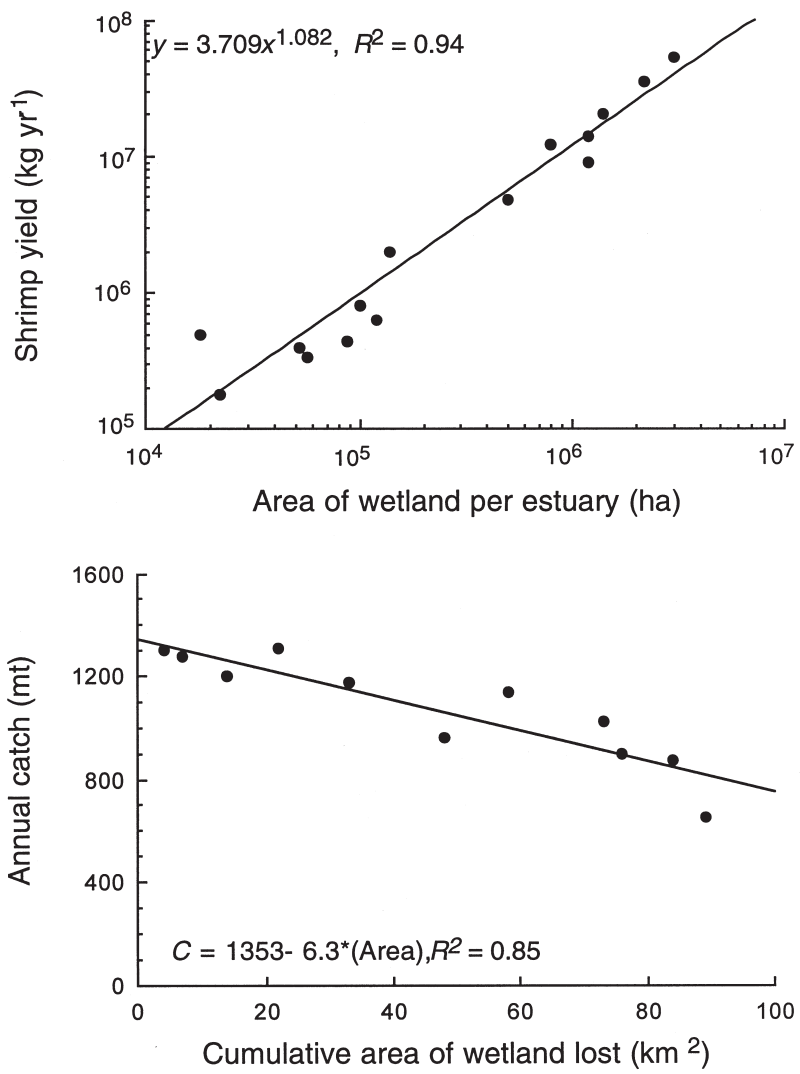

FIG. 12. - Top: Harvest by the shrimp fishery off Louisiana in relation to the area of adjoining coastal wetland. Bottom: Metric tons of shrimp caught annually off Louisiana in relation the cumulative loss of adjoining coastal wetland. Data compiled by Turner (1992). 
those areas has fallen, and the reduction in catch can be related to the cumulative loss of coastal wetlands in the Louisiana area (Fig. 12 bottom). These data speak of a clear relationship between the relative area of coastal wetlands, and the commercial harvest of shrimp from nearby deeper waters. The links between these two spatially separate variables are that juvenile shrimp use adjacent wetlands as nurseries, and that materials exported from wetlands support the coastal food web on which adult shrimp depend.

The migration of fish and shrimp out of estuaries is another example of a reciprocal exchange across boundaries of ecological tesserae. Much as in the case of salt aerosol exchanges, the amounts of nutrients transported in and out of estuaries via organism migration is orders of magnitude lower than the hydrographically controlled transports (Valiela and Teal, 1979; Deegan, 1993).

Invasions by organisms from one ecological tessera to another are not rare. A terrestrial example can be found in feeding patterns of bird assemblages (Fig. 13). Birds from late succession parcels of land- scape (forests) tend to feed in parcels of environment of earlier succession (fields), particularly during the breeding season when demand for food is highest.

In most estuarine situations (but not all), species from down-gradient move up-gradient to find such richer food supplies. It is as if species from downgradient environments live in a relatively more competitive environment, and send their young to upgradient environments where some adaptation allows exploitation of a less intensively used resource (the epitome of such relationships might be the pole-ward migration of birds during the breeding season). The magnitude of the effects exerted on the estuarine system by the invaders is likely minor because of the rarity of the invaders relative to the abundance of the resident species, at least in the example we used.

Coastal environments such as the ones we are describing have been unusually subject to invasion by species from elsewhere (Carlton, 1996), via anthropogenic intervention and by natural processes. Such invasions at times have considerably

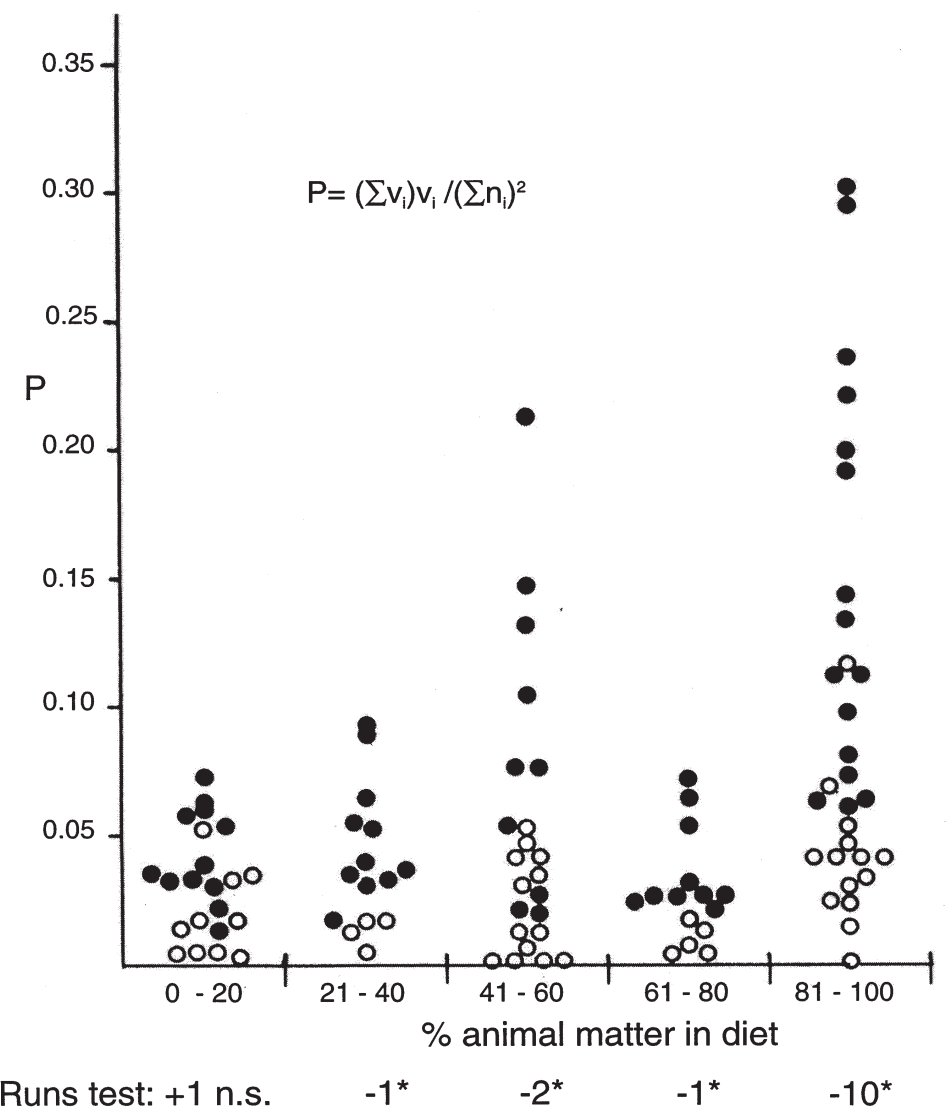

FIG. 13. - A measure of the frequency of visitor bird species (P) found in forests (white circles) and in fields (black circles) in each of four intervals of \% carnivory. The more carnivorous the bird, the more likely it visits adjoining parcels for feeding. "n" is number of species, "v" is number of visitor species in the assemblages of birds recorded. "n.s." = runs test not significant, "**" = runs test significant at 0.05 probability. Data compiled from published sources, and published in Valiela (1971). 
restructured the composition of local communities. It may be that coastal systems share some as yet unidentified features that make for such susceptibility to invasions; study of possible commonalities within both receiving and donor sites might be of considerable ecological interest.

\section{CONCLUSIONS}

Ecological boundaries per se are ambiguous and perhaps pragmatically their definition is best ignored. On the other hand, exchanges among adjoining ecological units on either side of the undefined boundaries are not only empirically demonstrable, but also may have potentially major consequences for the structure and organization of the adjoined ecological tesserae.

In the examples we reviewed above, the direction of the control by processes across boundaries was invariably asymmetrical, and dominated by water transport. We could document reciprocal effects -as in the instances of aerosol transport, and juvenile organism invasions from deeper- to shallower water tesserae- but these reciprocal mechanisms either were of a considerably lesser magnitude, or likely had minor effects, compared to transport of materials by water down-gradient.

There is no doubt that fundamentally important processes exert their influences on adjoining ecological units across their boundaries. Tesserae of ecological mosaics are not isolated units but may be coupled by forces generated by properties of adjoining, or even distant and non-contiguous ecological units, as in the case of watershed land use and producers within estuaries.

Most inter-tesseral exchanges are carried out via physical mechanisms such as water flow and wind, with a smaller role for organismal movement. It is difficult to generalize about ecological properties of ecological donor vs receptor tesserae: a parsimonious explanation may be that for the most part, and in most circumstances, physical transport simply forces the exchanges. It should take only a little coaxing to perhaps convince Margalef to provide us with a more imaginative explanation.

\section{ACKNOWLEDGEMENTS}

The work on which this paper is based was supported by grants from the National Center for Envi- ronmental Assessment, Office of Research and Development, U.S. EPA, the U.S. National Science Foundation LMER and REU grants, and National Estuarine Research Reserve and Cooperative Institute and Estuarine Technology grants from the National Oceanic and Atmospheric Administration. Support was also provided by the Woods Hole Oceanographic Institution Sea Grant Program, the Massachusetts Institute of Technology Sea Grant Program, by Graduate Fellowships to K. Kroeger, G. Tomasky, and D. Lawrence from the National Oceanic and Atmospheric Administration, and by the Palmer/McLeod Fellowship to K. Kroeger.

\section{REFERENCES}

Bowen, J.L. and I. Valiela. - 2001a. The ecological effects of urbanization of coastal watersheds: Historical increases in nitrogen loads and eutrophication of Waquoit Bay estuaries. Can. J. Fish. Aquat. Sci., 58: 1489-1500.

Bowen, J.L. and I. Valiela. - 2001b. Historical changes in atmospheric nitrogen deposition to Cape Cod, Massachusetts, USA. Atmos. Environ., 35: 1039-1051.

Carlton, J.T. - 1996. Marine bioinvasions: The alteration of marine ecosystems by non-indigenous species. Oceanography, 9: 36-43.

Cubbage, A., D. Lawrence, G. Tomasky and I. Valiela. - 1999. Relationship of reproductive output in Acartia tonsa, chlorophyll concentration, and land-derived nitrogen loads in estuaries of Waquoit Bay, Massachusetts. Biol. Bull., 197: 294-295.

Deegan, L.A. - 1993. Nutrient and energy transport between estuaries and coastal marine ecosystems by fish migration. Can. J. Fish. Aquat. Sci., 50: 74-79.

Dennison, W.C. and R.S. Alberte. - 1982. Photosynthetic responses of Zostera marina L. (eelgrass) to in situ manipulations of light intensity. Oecologia, 55: 137-144.

Duarte, C.M. - 1995. Submerged aquatic vegetation in relation to different nutrient regimes. Ophelia, 41: 87-112.

Foreman, K., G. Tomasky, L.A. Soucy and I. Valiela. - (Submitted). Responses of phytoplankton production to land-derived nitrogen loads in Waquoit Bay, Massachusetts, USA. Aquatic Ecology.

Hauxwell, J., J. Cebrián, C. Furlong and I. Valiela. - 2001. Macroalgal canopies contribute to eelgrass (Zostera marina) decline in temperate estuarine ecosystems. Ecology, 82: 10071022.

Hopkinson, C.S., Jr. - 1985. Shallow-water benthic and pelagic metabolism: Evidence of heterotrophy in the nearshore Georgia Bight. Mar. Biol., 87: 19-32.

Howarth, R.W., G. Billen, D. Swaney, A. Townsend, N. Jaworski, K. Lajtha, J.A. Downing, R. Elmgren, N. Caraco, T. Jordan, F. Berendse, J. Freney, V. Kudeyarov, P. Murdoch and Z. ZhoaLiang. - 1996. Regional nitrogen budgets and riverine $\mathrm{N}$ and $\mathrm{P}$ fluxes for the drainages to the North Atlantic Ocean: Natural and human influences. Biogeochemistry, 35: 75-139.

Johnes, P.J. - 1996. Evaluation and management of the impact of land use changes on the nitrogen and phosphorus load delivered to surface waters: The export coefficient modeling approach. $J$. Hydrol., 183: 323-349.

Lawrence, D.J. - 2000. Estuarine calanoid copepod abundance in Waquoit Bay, MA: Effects of season, salinity, and land-derived nitrogen loading. M. S. thesis, Boston Univ.

Margalef, R. - 1962. Adaptación, ecología y evolución: Nuevas formas de plantear antiguos problemas. Bol. R. Soc. Esp. Hist. Nat. (B), 60: 231-246

Margalef, R. - 1967. Perspectives in ecological theory, The University of Chicago Press, Chicago.

Margalef, R. - 1974. Ecologia. Omega, Barcelona.

Margalef, R. - 2000. Widening vistas: Toward an ecology tailored to our problems. Fundación Cesar Manrique, Madrid. 
McClelland, J.W. and Valiela, I. - 1998. Linking nitrogen in estuarine producers to land-derived sources. Limnol. Oceanogr., 43: $577-585$

McClelland, J.W., I. Valiela and R.H. Michener. - 1997. Nitrogenstable isotope signatures in estuarine food webs: A record of increasing urbanization in coastal watersheds. Limnol. Oceanogr., 42: 930-937.

Nixon, S.W. - 1980. Between coastal marshes and coastal waters a review of twenty years of speculation and research on the role of salt marshes in estuarine productivity and water chemistry. In: P. Hamilton and K.B. MacDonald (eds.), Estuarine and wetland processes with emphasis on modeling, pp. 437-526. Plenum Press, New York.

Nixon, S.W. - 1995. Coastal marine eutrophication: A definition, social causes, and future concerns. Ophelia, 41: 199-219.

Odum, E.P. - 1971. Fundamentals of ecology, $3^{\text {rd }}$ edition. W.B. Saunders, Philadelphia.

Pabich, W.J., H.F. Hemond and I. Valiela. - (Submitted). Denitrification rates in groundwater, Cape Cod, USA: Control by $\mathrm{NO}_{3}$ and DOC concentrations. Geochim. Cosmochim. Acta.

Pabich, W.J., I. Valiela and H.F. Hemond. - (In press). Relationship between DOC concentration, vadose zone thickness and depth below water table in groundwater of Cape Cod, U.SA. Biogeochemistry.

Pace, M.L., S.E.G. Findlay and D. Lints. - 1992. Zooplankton in advective environments: The Hudson River community and a comparative analysis. Can. J. Fish. Aquat. Sci., 49: 1060-1069.

Peckol, P., B. DeMeo-Anderson, J. Anderson, I. Valiela, M. Maldonado and J. Yates. - 1994. Growth nutrient uptake capacities and tissue constituents of the macroalgae Cladophora vagabunda and Gracilaria tikvahiae related to site specific nitrogen loads. Mar. Biol., 121: 175-185.

Risser, P.G. - 1990. The ecological importance of land-water ecotones. In: R. J. Naiman and H. Décamps (eds.), The ecology and management of aquatic-terrestrial ecotones, Vol. 4. Man and Biosphere Series, pp. 7-22. Parthenon Publ. Group.

Sand-Jensen, K. and J. Borum. - 1991. Interactions among phytoplankton, periphyton, and macrophytes in temperate freshwaters and estuaries. Aquat. Bot., 41: 137-175.

Shelford, V.E. - 1963. The ecology of North America. University of Illinois Press, Urbana, Illinois.

Short, F.T. and D.M. Burdick - 1996. Quantifying eelgrass habitat loss in relation to housing development and nitrogen loading in Waquoit Bay, Massachusetts. Estuaries, 19: 730-739.

Slobodkin, L.B. - 1964. Growth and regulation of animal populations. Holt, Rinehart and Winston, Inc, USA.

Stieve, E., I. Valiela, J. Hauxwell and J. McClelland. - (Submitted) Macrophyte abundance in Waquoit Bay, MA: Effects of landderived nitrogen loads, light, and canopy depth. Aquat Bot.

Taylor, D.I. and B.R. Allanson. - 1995. Organic carbon fluxes between a high marsh and estuary, and the inapplicability of the Outwelling Hypothesis. Mar. Ecol. Prog. Ser, 120: 263-270.

Teal, J.M. - 1962. Energy flow in the salt marsh ecosystem of Georgia. Ecology, 43: 614-624.
Tomasky, G. and I. Valiela. - (Submitted). Residence time mediated response of estuarine phytoplankton to nitrogen loads. Estuarine, Coastal and Shelf Science.

Turner, R.E. - 1992. Coastal wetlands and penaeid shrimp habitat. In: R.H. Shroud (ed.), Stemming the tide of coastal fish habitat loss, pp. 97-104. National Coalition for Marine Conservation, Inc., Savannah.

Valiela, I. - 1971. Food specificity and community succession: Preliminary ornithological evidence for a general framework. General Systems, 16: 77-84.

Valiela, I. - 1983. Nitrogen in salt marsh ecosystems. In: E.J. Carpenter and D.G. Capone (eds.), Nitrogen in the marine environment, pp. 649-678. Academic Press, New York.

Valiela, I. and M.L. Cole - (In press). Comparative evidence that salt marshes and mangroves may protect seagrass meadows from land-derived nitrogen loads. Ecosystems.

Valiela, I., G. Collins, J. Kremer, K. Lajtha, M. Geist, B. Seely, J. Brawley and C-H. Sham. - 1997. Nitrogen loading from coastal watersheds to receiving estuaries: New method and application. Ecol. Appl., 7: 358-380.

Valiela, I., K. Foreman, M. LaMontagne, D. Hersh, J. Costa, P. Peckol, B. DeMeo-Anderson, C. D'Avanzo, M. Babione, C-H. Sham, J. Brawley and K. Lajtha. - 1992. Couplings of watersheds and coastal waters: Sources and consequences of nutrient enrichment in Waquoit Bay, Massachusetts. Estuaries, 15: 443-457.

Valiela, I., M. Geist, J. McClelland and G. Tomasky. - 2000a. Nitrogen loading from watersheds to estuaries: Verification of the Waquoit Bay nitrogen loading model. Biogeochemistry, 49: 277-293.

Valiela, I., P. Peckol, C. D’Avanzo, J. Kremer, D. Hersh, K. Foreman, K. Lajtha, B. Seely, W.R. Geyer, T. Isaji and R. Crawford. - 1998. Ecological effects of major storms on coastal watersheds and coastal watersheds: Hurricane Bob on Cape Cod. J. Coast. Res., 14: 218-238.

Valiela, I., P. Peckol, C. D’Avanzo, K. Lajtha. J.N. Kremer, W.R. Geyer, K. Foreman, D. Hersh, B. Seely, T. Isaji and R. Crawford. - 1996. Hurricane Bob on Cape Cod. Am. Sci., 84: 154-165.

Valiela, I. and J.M. Teal. - 1979. The nitrogen budget of a salt marsh ecosystem. Nature, 280: 652-656.

Valiela, I., J.M. Teal, S.D. Allen, R. Van Etten, D. Goehringer and S. Volkmann. - 1985. Decomposition in salt marsh ecosystems: The phases and major factors affecting disappearance of aboveground organic matter. J. Exp. Mar. Biol. Ecol., 89: 29-54.

Valiela, I., G. Tomasky, J. Hauxwell, M.L. Cole, J. Cebrián and K.D. Kroeger. - 2000b. Operationalizing sustainability: Management and risk assessment of land-derived nitrogen loads to estuaries. Ecol. Appl., 10: 1006-1023.

Vallino, J.J. and C.S. Hopkinson Jr. - 1998. Estimation of dispersion and characteristic mixing times in Plum Island Sound Estuary. Estuar. Coast. Shelf Sci., 46: 333-350.

Werme, C. - 1981. Resource partitioning in a salt marsh fish community. Ph.D. thesis., Boston Univ. 